\title{
The effect of LH, FSH and pregnant mares' serum gonadotrophin on ornithine decarboxylase activity in thecal and granulosa tissue during follicular growth and atresia in laying hens (Gallus domesticus)
}

\author{
D. G. Armstrong \\ AFRC Roslin Institute (Edinburgh), Roslin, Midlothian, EH25 9PS, UK
}

\begin{abstract}
The effect of ovine LH, porcine FSH and pregnant mares' serum gonadotrophin (PMSG) on the activity of ornithine decarboxylase activity in theca and granulosa tissue during folliculogenesis in laying hens is described. The changes in the activity of ornithine decarboxylase induced by hormonal challenge was used to measure the sensitivity of the tissue to the hormone. Thecal tissue from small $(<6 \mathrm{~mm})$ follicles showed a large increase in the activity of ornithine decarboxylase $3 \mathrm{~h}$ after treatment with LH, FSH and PMSG, in vivo, whereas ornithine decarboxylase activity in thecal tissue from large $(>8 \mathrm{~mm})$ preovulatory follicles and atretic follicles did not respond to any of the hormonal treatments. Ornithine decarboxylase activity in granulosa tissue from the largest preovulatory follicle increased significantly $3 \mathrm{~h}$ after treatment with LH and PMSG in vivo; no effect was observed with FSH. Granulosa tissue from the third largest and fifth largest preovulatory follicles were refractory to the hormonal treatments. Basal activity of ornithine decarboxylase in granulosa tissue from preovulatory follicles increased as the follicles approached ovulation, whereas the activity in thecal tissue from the same follicles decreased. The difference in sensitivity of thecal tissue from small and large preovulatory follicles towards gonadotrophin treatment in vivo is correlated with the difference in the observed rate of atresia occurring within the two groups of follicles. Atresia is the common fate for small follicles, whereas it is a rare event for large preovulatory follicles under normal physiological conditions. It is suggested that the decrease in sensitivity of thecal tissue towards gonadotrophin during recruitment of small follicles into the preovulatory follicular hierarchy is one reason for the difference in the incidence of atresia occurring within the two populations of follicles.
\end{abstract}

\section{Introduction}

The ovaries of laying hens contain a hierarchy of large yellow follicles $(>8 \mathrm{~mm}$ ), which allows a mature follicle to ovulate on successive days throughout a laying sequence (Fraps, 1955; Gilbert and Wood-Gush, 1979; Etches, 1990). The hierarchy is maintained by the recruitment of small follicles $(<8 \mathrm{~mm})$ into the hierarchy (Gilbert et al., 1983; Waddington et al., 1985).

Small follicles $(<8 \mathrm{~mm})$ are present in a graded-size sequence; fewer follicles are present in each size class as they increase in size. Small follicles are either recruited into the follicular hierarchy or, more commonly, they undergo atresia, eventually being reabsorbed into the ovary (Gilbert et al., 1983). In laying hens, once a follicle is recruited into the hierarchy, it is committed to ovulate within 5-7 days, as atresia within this group of follicles is rare under normal physiological conditions (Gilbert et al., 1981, 1983; Etches et al., 1984).

The biochemical and physiological events involved in the control of avian follicular growth and the initiation of atresia

Received 24 May 1993. are not known. However, a central role for gonadotrophins is well established. In mammals, pregnant mares' serum gonadotrophin (PMSG) has been shown to promote the recruitment of antral follicles and to prevent some normal, small follicles from becoming atretic (Moor et al., 1984; Greenwald and Terranova, 1988). In hens, treatment with PMSG and FSH in vivo increases the rate of recruitment of small follicles into the follicular hierarchy (Opel and Nalbandov, 1961). Atresia can be induced in small and large follicles from laying hens after treatment with an antiserum to partially purified chicken LH (Sharp et al., 1978). Injections of LH alone can also induce atresia in large preovulatory follicles; the effectiveness of the treatment depends on the stage of the ovulatory cycle at which the hormone is given (Gilbert et al., 1981). An early event associated with the development of atresia of small follicles in hens is a reduction in their sensitivity to $\mathrm{LH}$ and a concomitant loss in aromatase activity (Armstrong, 1985, 1986a; Wells et al., 1985a). Gilbert $e$ al. (1985) suggested that these early changes are a consequence of the disruption of the vascular system in the small follicles destined to become atretic. In the study reported here, the growth of ovarian follicles from domestic 
fowls was monitored by measuring the interaction of gonadotrophins with granulosa and thecal tissue from follicles at various stages of development. The interaction of the gonadotrophin preparations with follicular tissue was monitored by measuring changes in the activity of the enzyme ornithine decarboxylase induced by the hormone treatment. Ornithine decarboxylase catalyses the rate limiting step in the biosynthesis of polyamines (putriscene, spermidine and spermine) (Pegg and McCann, 1982; Grillo, 1985), which play important roles in the structure and function of nucleic acids, including DNA replication, transcription and translational processes. Ornithine decarboxylase activity is correlated with the rate of tissue growth (Russell and Snyder, 1968; Janne et al., 1978). Its activity in target tissues rises markedly in response to hormones, growth factors and tumour promoters (Pegg and McCann, 1982) and it has been used successfully as a marker for gonadotrophin sensitivity in previous studies concerned with the control of follicular growth in the fowl (Armstrong, $1986 a, b, c)$.

The results of this investigation indicate that the sensitivity of follicular tissue towards gonadotrophins changes during folliculogenesis, and provides information regarding the involvement of these hormones in the control of avian ovarian follicular growth and atresia.

\section{Materials and Methods}

\section{Animals}

A flock of laying birds (ISA Browns; weight \pm SEM $=$ $2.20 \pm 0.04 \mathrm{~kg}, n=56$ ) were housed individually in standard cages under a lighting regimen of $14 \mathrm{~h}$ light: $10 \mathrm{~h}$ dark with free access to food and water. During the course of the experiment the ages of the birds ranged from 25 to 43 weeks of age and all laid regular egg sequences of five or more eggs. All cages were fitted with an automatic timing device measuring the time of oviposition to within 1 min.

\section{Hormone preparations}

Pregnant mares' serum gonadotrophin (PMSG; gonadotrophin-FSH, specific activity $3600 \mathrm{iu} \mathrm{mg}^{-1}$ protein) was obtained from Paines Byrne Ltd (Greenford). Porcine FSH (NIH-P2) and ovine LH (NIH-H-25 were supplied by NIADK (NIH, Bethesda). The various doses of PMSG were made up in $300 \mu \mathrm{l}$ lactose solution $\left(5 \mathrm{mg} \mathrm{ml}^{-1}\right)$, whereas FSH and LH were prepared in $100 \mu \mathrm{l}$ distilled water containing BSA (1\%; w:v). All hormone preparations were stored at $-20^{\circ} \mathrm{C}$ until required.

\section{Chemicals}

L- $\left[1-{ }^{14} \mathrm{C}\right]$ ornithine hydrochloride (Amersham International plc, Bucks) was stored at $4^{\circ} \mathrm{C}$ in ethanol $(2 \%, w: v)$ at a specific activity of $2.04 \mathrm{GBq} \mathrm{nmol}^{-1}$. D,L- $\alpha$-Difluoromethylornithine was a gift from Merrill Dow Research Institute (Strasbourg). All other chemicals were obtained from Sigma Chemical Co Ltd (Poole, Dorset) and were of Analar grade.

\section{Gonadotrophin treatment and collection of tissue}

Birds were injected into the wing vein between 11.00 and $12.00 \mathrm{~h}$ on the morning of an oviposition with either LH, FSH or PMSG. Control birds were injected with either $300 \mu \mathrm{l}$ lactose $\left(5 \mathrm{mg} \mathrm{ml}^{-1}\right)$ or $100 \mu \mathrm{l} \mathrm{BSA}(1 \%$, w:v). All birds were killed $3 \mathrm{~h}$ after treatment by an overdose of sodium pentabarbitone (Expiral: Ceva Ltd, Watford, Herts) and the ovaries removed and rinsed in physiological saline. Thecal and granulosa tissue were collected from the largest (F1), third largest (F3) and fifth largest (F5) preovulatory follicles and homogenized individually in $5 \mathrm{ml}$ Tris buffer $\left(50 \mathrm{mmol} \mathrm{l}^{-1} ; \mathrm{pH} 8.2\right.$ at $\left.2^{\circ} \mathrm{C}\right)$ containing dithiothreitol $\left(5 \mathrm{mmol} 1^{-1}\right), \operatorname{EDTA}(1 \mathrm{mmol}$ $\left.1^{-1}\right)$ and pyrodoxal phosphate $\left(1 \mathrm{nmol} \mathrm{l}^{-1}\right)$ using a polytron homogenizer. The homogenates were centrifuged at $600 \mathrm{~g}$ for $10 \mathrm{~min}$ at $4^{\circ} \mathrm{C}$ and the supernatants stored overnight at $4^{\circ} \mathrm{C}$ before assaying for enzyme activity.

Thecal tissue was also collected from small $(<6 \mathrm{~mm})$ normal, atretic and grossly atretic follicles. Atretic follicles were distinguished from normal follicles by either the presence of small haemorrhages on their surface or, in the case of grossly atretic follicles, by their deformed appearance (Gilbert, 1979; Gilbert et al., 1983). The thecal tissue from small nonatretic follicles of the appropriate size ( $1-3 \mathrm{~mm}$ diameter follicles: $n=8-10$ per bird and 3-6 mm diameter follicles: $n=6-10$ per bird), atretic follicles ( $n=4-10$ per bird) and grossly atretic follicles $(n=3$ per bird) were pooled, according to type and homogenized in $5 \mathrm{ml}$ homogenization medium. Before homogenization, the small follicles were slit with a scalpel and the yolk and adhering granulosa tissue gently squeezed out. Histological evidence indicated that the thecal preparations were free of contaminating granulosa cells (results not shown).

\section{Enzyme assay}

The activity of ornithine decarboxylase (L-omithine carboxylyase; EC 4.1.1.17) was measured as described by Amstrong (1986a). Briefly, this involved incubating the tissue homogenate $(100 \mu \mathrm{l})$ with $200 \mu \mathrm{l}$ of a solution containing pyrodoxal phosphate $\left(0.3 \mathrm{mmol} \mathrm{l}^{-1}\right)$ and $\mathrm{L}\left[\mathrm{I}^{14} \mathrm{C}\right]$ ornithine $(1.85 \mathrm{~Bq}$; specific activity $2.04 \mathrm{GBq} \mathrm{nmol}^{-1}$ ). The incubation was carried out at $37^{\circ} \mathrm{C}$ for $60 \mathrm{~min}$ in sealed plastic tubes containing filter-paper inserts soaked in methyl benzithonium hydroxide. At the end of the incubation, $100 \mu \mathrm{l}$ sulfuric acid $(5.0 \mathrm{mmol}$ $\left.1^{-1}\right)$ was injected into the tube and the incubation was continued for a further $60 \mathrm{~min}$. Incubations were performed in triplicate and tissue blanks containing BSA $(0.1 \%$, w:v $)$ and total blanks containing $\mathrm{D}, \mathrm{L}-\boldsymbol{\alpha}$-difluoromethylomithine $\left(5 \mu \mathrm{mol} \mathrm{I}^{-1}\right)$, an irreversible inhibitor of ornithine decarboxylase (Metcalf et al., 1978), were included. After incubations the filter-paper inserts were removed and radioactivity was measured in an LKB RackBeta II liquid scintillation counter using the external standard channels ratio mode.

Protein was measured by the method of Bradford (1976) using BSA as the protein standard and enzyme activities were expressed as pmol $\mathrm{CO}_{2}$ released $\mathrm{h}^{-1} \mathrm{mg}^{-1}$ protein.

\section{Statistical analysis}

After transformation to a logarithmic scale, the data were analysed by an analysis of variance using a split-plot design 
Table 1. The effect of gonadotrophin treatments on thecal ornithine decarboxylase activity in ovarian follicles from laying hens

\begin{tabular}{lccccc}
\hline & & \multicolumn{2}{c}{ Thecal ornithine decarboxylase activity (pmol $\mathrm{CO}_{2} \mathrm{~h}^{-1} \mathrm{mg}^{-1} \mathrm{protein}^{2}$} \\
\cline { 2 - 6 } Treatment & F1 & F3 & F5 & SY & \\
\hline Control & $30.4 \pm 10.9$ & $61.9 \pm 11.6$ & $145.1 \pm 33.9$ & $55.3 \pm 18.2$ & $42.7 \pm 14.4$ \\
LH $(40 \mu \mathrm{g})$ & $21.6 \pm 11.2$ & $55.2 \pm 11.0$ & $152.6 \pm 27.3$ & $165.2 \pm 21.5^{*}$ & $139.7 \pm 20.0^{*}$ \\
FSH $(500 \mu \mathrm{g})$ & $27.2 \pm 8.5$ & $63.0 \pm 17.1$ & $138.8 \pm 21.6$ & $141.8 \pm 18.9^{*}$ & $151.0 \pm 18.7^{*}$ \\
PMSG $(300 \mathrm{iu})$ & $23.2 \pm 9.9$ & $58.3 \pm 21.0$ & $127.1 \pm 25.6$ & $211.7 \pm 38.5^{*}$ & $213.1 \pm 61.4^{*}$ \\
\hline
\end{tabular}

Results are expressed as means $\pm \operatorname{SEM}(n=5), \mathrm{F} 1, \mathrm{~F} 3$ and F5 represent the largest, third largest, and fifth largest preovulatory follicle, respectively. SY and SW represent small follicles $3-6 \mathrm{~mm}$ in diameter and $1-3 \mathrm{~mm}$ in diameter, respectively. ${ }^{*}$ Significantly different $(P<0.001)$ from control.

PMSG: pregnant mares' serum gonadotrophin.

Table 2. The effect of gonadotrophin treatments on granulosa ornithine decarboxylase activity in ovarian follicles from laying hens

\begin{tabular}{lccc}
\hline & \multicolumn{4}{c}{ Granulosa ornithine decarboxylase activity $\left(\mathrm{pmol} \mathrm{CO} \mathrm{h}^{-1} \mathrm{mg}^{-\mathrm{I}}\right.$ protein) } \\
\cline { 2 - 4 } Treatment & $\mathrm{F} 1$ & $\mathrm{~F} 3$ & $\mathrm{~F} 5$ \\
\hline & & & \\
Control & $286.0 \pm 70.7$ & $137.6 \pm 25.5$ & $62.6 \pm 24.2$ \\
LH $(40 \mu \mathrm{g})$ & $589.0 \pm 89.1^{*}$ & $130.5 \pm 31.1$ & $60.7 \pm 15.2$ \\
FSH $(500 \mu \mathrm{g})$ & $397.5 \pm 125.8$ & $142.9 \pm 41.0$ & $69.1 \pm 24.2$ \\
PMSG $(300 \mathrm{iu})$ & $622.4 \pm 102.4^{*}$ & $158.4 \pm 48.1$ & $52.2 \pm 23.1$ \\
\hline
\end{tabular}

Results are expressed as means $\pm \operatorname{SEM}(n=5)$. F1, F3 and F5 represent the largest, third largest, and fifth largest, preovulatory follicle, respectively. ${ }^{*}$ Significantly different $(P<0.001)$ from control.

PMSG: pregnant mares' serum gonadotrophin.

(Steele and Torrie, 1980). Differences within tissues between controls and treatments were tested by the method of least significant differences using a pooled residual mean square.

\section{Results}

Effect of a single dose of ovine $L H$, porcine FSH and PMSG on ornithine decarboxylase activity in ovarian follicular tissue

All of the mammalian hormone preparations significantly increased ornithine decarboxylase activity in thecal tissue from small $(<6 \mathrm{~mm}$ ) nonatretic follicles (Table I). PMSG (300 iu) was the most effective treatment followed by ovine $\mathrm{LH}(40 \mu \mathrm{g})$ and then FSH $(500 \mu \mathrm{g})$. When the enzyme activities were expressed as activity $\mathrm{mg}^{-1}$ protein, no difference was apparent between the two sizes of small follicles (Table 1). However, when the enzyme activity was expressed on a per follicle basis (results not shown) the 1-3 mm diameter follicles had a lower basal activity than did the 3-6 mm diameter follicles, and they showed a larger relative increase in enzyme activity after hormone treatments. In contrast to the small $(<6 \mathrm{~mm})$ follicles, ornithine decarboxylase activity in thecal tissue from the large preovulatory follicles (F1, F3 and F5) were not affected by the hormonal treatments (Table 1).

Ornithine decarboxylase activity in granulosa tissue from the largest preovulatory follicle (FI) was significantly higher after LH and PMSG treatments in vivo (Table 2). Although the omithine decarboxylase activity in FI granulosa was also increased by the FSH treatment, the variance of the data was too large to detect any significant changes. The enzyme activity in granulosa tissue from the F3 and F5 follicles was unaffected by any of the hormone treatments.

In contrast to the basal activity of ornithine decarboxylase in granulosa tissue from preovulatory follicles, which increased as the follicles approached ovulation, the ornithine decarboxylase activity in thecal tissue from corresponding preovulatory follicles decreased (Tables 1 and 2).

Effect of various doses of PMSG on ornithine decarboxylase activity in ovarian follicular tissue

Thecal tissue from small follicles $1-3 \mathrm{~mm}$ in diameter was more sensitive to PMSG than was thecal tissue from follicles 3-6 $\mathrm{mm}$ in diameter (Table 3). The former was stimulated by a dose of $30 \mathrm{iu}$, whereas the latter showed no change in ornithine decarboxylase activity with this dose of PMSG. The minimum dose of PMSG that caused a significant increase in follicles 3-6 mm in diameter was 75 iu. Maximum activity in follicles of both of these sizes was observed with a dose of $300 \mathrm{iu}$.

Granulosa tissue showed an initial decrease in enzyme activity and a minimum was observed at $75 \mathrm{iu}$. Thereafter, activity increased, reaching a maximum at 300 iu PMSG. A dose of 150 iu PMSG had no effect on granulosa ornithine decarboxylase activity. 
Table 3. Stimulation of omithine decarboxylase activity by pregnant mares' serum gonadotrophin (PMSG) in granulosa tissue from the largest preovulatory follicle and thecal tissue from small follicles from laying hens

\begin{tabular}{|c|c|c|c|}
\hline \multirow[b]{2}{*}{ PMSG (iu) } & \multicolumn{3}{|c|}{ Ornithine decarboxylase activity ( $\mathrm{pmol} \mathrm{CO}_{2} \mathrm{~h}^{-1} \mathrm{mg}^{-1}$ protein) } \\
\hline & Granulosa & Small yellow & Small white \\
\hline 0 & $175.7 \pm 43.5$ & $49.2 \pm 6.5$ & $39.2 \pm 6.0$ \\
\hline 30 & $115.0 \pm 21.3$ & $47.0 \pm 12.2$ & $78.3 \pm 25.1^{*}$ \\
\hline 75 & $37.6 \pm 11.8^{*}$ & $83.7 \pm 12.0^{*}$ & $85.3 \pm 4.6^{*}$ \\
\hline 150 & $176.0 \pm 49.0$ & $107.1 \pm 11.5^{*}$ & $94.8 \pm 23.3^{*}$ \\
\hline 300 & $1059 \pm 104^{*}$ & $164.9 \pm 38.6^{*}$ & $215.5 \pm 60.4^{*}$ \\
\hline 600 & $827.8 \pm 280.3^{*}$ & $140.3 \pm 6.3^{*}$ & $143.6 \pm 25.2^{*}$ \\
\hline
\end{tabular}

The results are expressed as means $\pm \operatorname{SEM}(n=4)$. Small yellow and small white represents follicles $3-6 \mathrm{~mm}$ and 1-3 mm in diameter, respectively. *Significantly different $(P<0.001)$ from control.

\section{Ornithine decarboxylase activity in atretic follicles}

Ovine LH $(40 \mu \mathrm{g})$ and porcine FSH $(500 \mu \mathrm{g})$ stimulated ornithine decarboxylase activity in both sizes of small follicle. In contrast, neither hormone treatment increased ornithine decarboxylase activity in the atretic, or grossly atretic follicles (Fig. 1). The basal activity of thecal ornithine decarboxylase decreased as atresia progressed.

\section{Discussion}

The activity of ornithine decarboxylase has been used as a marker for tissue growth and hormonal stimulation in a variety of experimental systems. The activity of ornithine decarboxylase increases under conditions of cell proliferation and differentiation (Marton and Morris, 1987; White et al., 1987; Hirvonen, 1989). When a hormone or growth factor produces a response in its target tissue, there is a concomitant change in ornithine decarboxylase activity (Janne et al., 1978).

The results reported here indicate that the effect of exogenous gonadotrophin on omithine decarboxylase activity in thecal and granulosa tissue from avian ovarian follicles depends on the stage of growth and atresia. The large increase in thecal ornithine decarboxylase activity in small $(<6 \mathrm{~mm})$ nonatretic follicles, $3 \mathrm{~h}$ after treatment, with either LH, FSH or PMSG is in marked contrast to the lack of change in thecal enzyme activity in large preovulatory follicles. In addition, small follicles become less sensitive to exogenous PMSG as they increase in size. The results are similar to the changes in thecal ornithine decarboxylase activity observed after the preovulatory increase in plasma LH concentrations (Armstrong, 1986a). Further evidence for a reduction in the sensitivity of thecal tissue from preovulatory follicles towards circulating gonadotrophins is the reduction in basal activity of ornithine decarboxylase in thecal tissue from follicles approaching ovulation. This decrease is mirrored by similar reductions in the activities of $3 \beta$ hydroxysteroid dehydrogenase and the aromatase enzyme system (Armstrong, 1982, 1984). It is concluded from these observations that, during normal follicular development in vitro, there is a general decrease in the response of thecal tissue towards gonadotrophins. The effect is particularly apparent

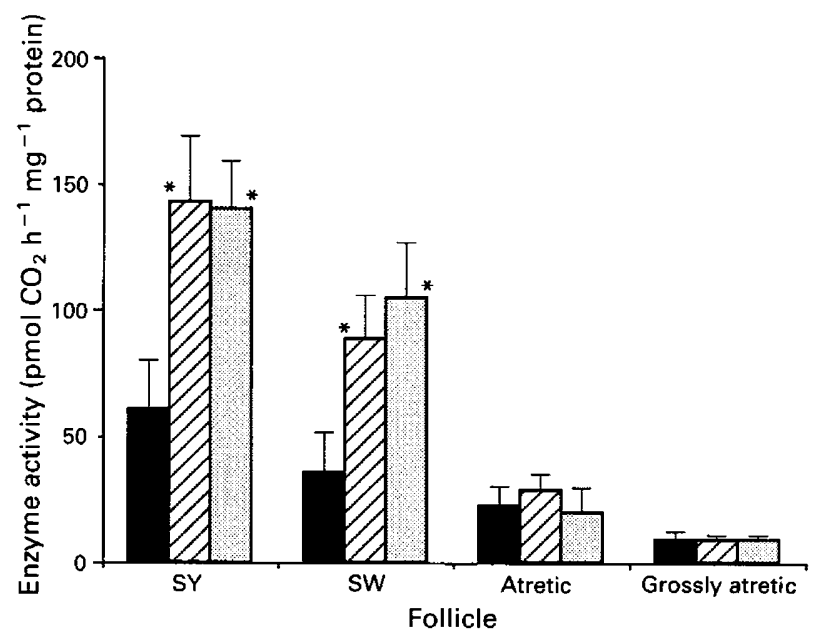

Fig. 1. The effect of gonadotrophin treatment on thecal ornithine decarboxylase activity (pmol $\mathrm{CO}_{2} \mathrm{~h}^{-1} \mathrm{mg}^{-1}$ protein) in small $(<6 \mathrm{~mm})$ nonatretic, atretic and grossly atretic follicles from laying

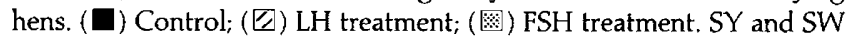
represent small nonatretic follicles $3-6 \mathrm{~mm}$ and $1-3 \mathrm{~mm}$ in diameter, respectively. ${ }^{*}$ Significantly different $(P<0.001)$ from controls. Values are means $\pm \operatorname{SEM}(n=4)$.

during the developmental period, when small follicles are recruited into the preovulatory follicular hierarchy.

Although significant binding of ${ }^{125}$ I-labelled bovine FSH to thecal tissue from large preovulatory follicles has been observed (Etches and Cheng, 1981), the results presented here indicate that exogenous gonadotrophin has less effect on thecal tissue from large preovulatory follicles than from small $(<6 \mathrm{~mm})$ follicles. In this respect, the observation that 8-bromo $3^{\prime} 5^{\prime}$ cyclic AMP and forskolin become less effective in stimulating androstenedione production in thecal tissue from follicles approaching ovulation (Marrone and Hertelendy, 1985) is relevant and indicates that the lack of response of thecal tissue from large preovulatory follicles towards gonadotrophin treatment in vivo may be due to the development of a lesion(s) in some post-receptor binding system involved in the transmission of the signal from the hormone-receptor complex into the 
thecal cells of the large preovulatory follicles. Superimposed on the reduced sensitivity of thecal ornithine decarboxylase activity towards exogenous gonadotrophin during the recruitment of small follicles into the hierarchy is the increase in basal activity of the enzyme during the same development period. The basal activity of the enzyme in thecal tissue from the F5 follicle approaches that observed in thecal tissue from small follicles fully stimulated by gonadotrophin. It is possible that upon recruitment of the follicle into the hierarchy, gonadotrophin remains bound to its receptor, thus maintaining a high basal enzyme activity, while preventing subsequent stimulation by exogenous hormone. In addition, locally acting growth factors, produced by the follicle during the recruitment process, are also likely to be involved in maintaining a high basal ornithine decarboxylase activity in thecal tissue at this time.

Juxtaposed with the reduction in gonadotrophin responsiveness of thecal tissue in small follicles, upon recruitment into the follicular hierarchy, is the increase, in vivo, in responsiveness of granulosa tissue towards LH and PMSG during the final phase of follicular development. The effect of PMSG on F1 granulosa tissue is probably due to the LH-like activity within the PMSG preparation (Stewart et al., 1976), although a direct effect of FSH on FI granulosa tissue cannot be excluded. Binding of ${ }^{125}$ I-labelled FSH to granulosa tissue homogenates was observed by Etches and Cheng (1981), but their preparation contained granulosa cells from follicles at various stages of development and direct comparisons cannot be made with the present results.

The observations, presented here, indicate that only granulosa cells from the largest preovulatory follicle respond to exogenous gonadotrophin. A similar result was observed by measuring the changes in ornithine decarboxylase activity in granulosa tissue after the preovulatory LH surge (Armstrong, 1986a). Measurement of progesterone content of granulosa cells, after LH treatment in vivo, also indicated that only the FI granulosa cells responded to exogenous gonadotrophin (Wells et al., 1985b). These observations are in direct contrast to those of Hammond et al. (1981) and Asem and Hertelendy (1985), who demonstrated that progesterone production by granulosa cells from all the large preovulatory follicles was higher after incubation with LH in vitro; albeit the FI granulosa cells were stimulated to a greater degree than granulosa cells from the less mature large follicles. Differences in the experimental design may be, at least, partly responsible for these differences, in that the present experiment and those described by Wells et al. (1985b) were performed in vivo, whereas those of Hammond $e t$ al. (1981) were carried out in vitro using dispersed granulosa cells. Taken together, these results indicate that, although granulosa cells from all the large preovulatory follicles have the capacity to respond to gonadotrophin in the intact follicle, in vitro, only granulosa tissue from the most mature follicle can do so. The avian granulosa cell develops through a complex sequence of events including an increase in their sensitivity towards LH (Hammond et al., 1981), the development of a functionally coupled adenylyl cyclase system, and the maturation of post-cyclic AMP steps (Asem and Hertelendy, 1985), including an increase in $3 \beta$-hydroxysteroid dehydrogenase activity (Armstrong, 1982) and cholesterol-20,22-desmolase activity (Asem and Hertelendy, 1985). The results presented here indicate that there is another level of control on granulosa function imposed by the intact follicle. In this case, it is possible that the access of gonadotrophin to the granulosa tissue of preovulatory follicles may, because of their lack of a direct blood supply, somehow modulate the supply of hormone to the granulosa cells of all but the most mature preovulatory follicle. It is also likely that growth factors play a role in this process. In mammals, a variety of growth factors have been shown to either potentiate or attenuate the response of granulosa cells towards gonadotrophins (Adashi and Rohan, 1992; Adashi et al., 1992; Giudice, 1992) and a similar mechanism probably operates in hens.

The response of ornithine decarboxylase activity in granulosa tissue from FI follicles towards PMSG in vivo shows clearly that granulosa tissue is significantly less sensitive to PMSG in vivo than is thecal tissue from small $(<6 \mathrm{~mm})$ follicles. The cause of the reduction in the enzyme activity in granulosa tissue caused by the 75 iu PMSG is not known. However, FSH has been shown to decrease ornithine decarboxylase activity in Sertoli cells of rats (Madhubala et al., 1987). Whatever the cause, the inhibition is overcome at higher doses of PMSG.

The results reported here indicate that an early event, associated with the onset of atresia in small follicles, is a loss in sensitivity towards circulating gonadotrophin, as indicated by the lack of response of thecal ornithine decarboxylase activity in atretic follicles to the hormone treatments. Whether this effect is due to the disruption of the blood supply to the atretic follicles, thus limiting the access of the hormone to its target tissue, or to a failure in some receptor-mediated event cannot be distinguished from these results.

In conclusion, the results of this investigation demonstrate that thecal tissue from small ovarian follicles is more sensitive to stimulation by gonadotrophins than is thecal tissue from large preovulatory follicles. This observation has relevance with respect to the development of atresia during folliculogenesis in hens. Atresia is the common fate for the majority of small $(<8 \mathrm{~mm})$ follicles, whereas it is a rare event, under normal physiological conditions, for the population of large preovulatory ovarian follicles from birds laying regular egg sequences (Gilbert et al., 1983). The growth of small follicles is critically dependent on plasma concentrations of FSH (Opel and Nalbandov, 1961). Any mechanism that reduces their sensitivity, or their exposure to hormonal stimuli will decrease their chances of recruitment into the follicular hierarchy (Armstrong, 1986c), and lead to atresia and eventual reabsorption back into the ovary. After recruitment into the hierarchy, however, thecal tissue becomes refractory towards FSH and this may explain why large preovulatory follicles do not normally become atretic.

The author wishes to thank C. Hogg for technical assistance.

\section{References}

Adashi E and Roban RM (1992) Intraovarian regulation. Peptidergic signalling systems Trends in Endocrinology and Metabolism 3 243-248

Adashi EY, Resnick CE, Hurwitz A, Ricciarellie E, Hernandez ER, Roberts CT, LeRoith D and Rosenfeld R (1992) The intra-ovarian IGF system Growth Regulation 2 10-15

Armstrong DG (1982) $3 \beta$-Hydroxy- $\Delta^{5}$-steroid dehydrogenase activity in rapidly growing ovarian follicles of the domestic fowl (Gallus domesticus) Journal of Endocrinology 93 415-421 
Armstrong DG (1984) Ovarian aromatase activity in the domestic fowl (Gallus domesticus) Joumal of Endocrinology 100 81-86

Armstrong DG (1985) Changes in aromatase activity in small ovarian follicles of the domestic fowl (Gallus domesticus) during growth and atresia Journal of Endocrinology 105 297-301

Armstrong DG (1986a) Changes in ornithine decarboxylase activity in ovarian follicles of the laying hen (Gallus domesticus) during the ovulatory cycle Journal of Endocrinology 110 211-216

Armstrong DG (1986b) Omithine decarboxylase activity in granulosa tissue from the laying hen (Gallus domesticus) during stimulation with ovine lutropin in vitro IRCS Medical Science 14 27-28

Armstrong DG (1986c) Ornithine decarboxylase activity in small ovarian follicles of the laying hen (Gallus domesticus). A comparison of follicles from several regions of the ovary Journal of Endocrinology 110 211-216

Asem EM and Hertelendy F (1985) Influence of follicular maturation on luteinizing hormone, cyclic $3^{\prime}, 5^{\prime}$-adenosine monophosphate, forskolin and cholesterol stimulated progesterone production Biology of Reproduction 32 $257-268$

Bradford MM (1976) A rapid and sensitive method for the quantitation of microgram quantities of protein utilizing the principal of protein-dye binding Analytical Biochemistry 72 248-254

Etches RJ (1990) The ovulatory cycle of the hen Critical Reviews In Poultry Biology 2 293-318

Etches RJ and Cheng KW (1981) Changes in the plasma concentration of luteinizing hormone, progesterone, oestradiol and testosterone and in the binding of follicle-stimulating hormone to the theca of follicles during the ovulation cycle of the hen (Gallus domesticus) Journal of Endocrinology 91 11-22

Etches RP, Williams JB and Rzasa J (1984) Effect of cortisone and dietary changes in the hen on ovarian function, plasma $\mathrm{LH}$ and steroids and the response to exogenous LHRH Journal of Reproduction and Fertility $\mathbf{7 0}$ $121-130$

Fraps RM (1955) Egg production and fertility in poultry. In Progress in the Physiology of Farm Animals Vol 2 pp 661-740 Ed. J Hammond. Butterworths, London

Gilbert AB (1979) Female genital organs. In Form and Function in Birds pp 273-360 Eds AS King and ) McClelland. Academic Press, London

Gilbert AB and Wood-Gush DGM (1979) Ovulatory and ovipository cycles. In Physiology and Biochemistry of the Domestic Fowl Vol 3 pp 1353-1378 Eds DJ Bell and BM Freeman. Academic Press, London

Gilbert AB, Davidson MF, Hardie MA and Wells JW (1981) The induction of atresia in the domestic fowl (Gallus domesticus) by ovine LH General and Comparative Endocrinology 44 344-349

Gilbert AB, Perry MM, Waddington D and Hardie MA (1983) The role of atresia in establishing the follicular hierarchy in the ovary of the domestic hen (Gallus domesticus) Joumal of Reproduction and Fertility $69221-227$

Gilbert AB, Perry MM, Walker MA and Waddington D (1985) Identification of atresia in small ovarian follicles of the domestic hen (Gallus domesticus) IRCS Medical Science 13 732-733

Giudice LC (1992) Insulin-like growth factors and ovarian follicular development Endocrine Reviews $13641-669$

Greenwald GS and Terranova PF (1988) Follicular selection and its control. In The Physiology of Reproduction pp 387-444 Eds E Knobel and JE Neill. Raven Press, New York

Grillo MA (1985) Metabolism and function of polyamines International Joumal of Biochemistry 17 943-948
Hammond RW, Burke WH and Hertelendy F (1981) Influence of follicular maturation on progesterone release in chicken granulosa cells in response to turkey and ovine gonadotrophin Biology of Reproduction 24 1048-1055

Hirvonen A (1989) Omithine decarboxylase activity and the accumulation of its mRNA during early stages of liver regeneration Biochimica et Biophysica Acta 1007, 120-123

Janne J, Poso H and Raina A (1978) Polyamines in rapid growth and cancer Biochimica et Biophysica Acta 463 241-293

Madhubala R, Shubhada S, Steinberger A and Tsai Y (1987) Inhibition of ornithine decarboxylase activity by follicle stimulating hormone in primary cultures of rat Sertoli cells Journal of Andrology 8 383-387

Marrone BL and Hertelendy F (1985) Decrease in androstenedione production with increased follicular maturation in thecal cells from the domestic hen (Gallus domesticus) Journal of Reproduction and Fertility 74 543-550

Marton LM and Morris DR (1987) Molecular and cellular functions of the polyamines. In Inhibition of Polyamine Metabolism: Biological Significance and Basis For New Therapies pp 79-105 Eds PP McCann and AE Pegg. Academic Press, San Diego

Metcalf BW, Beg P, Danzin L, Jung MJ, Casara P and Vevert JP (1978) Catalytic irreversible inhibition of mammalian ornithine decarboxylase (EC 4.1.1.17) by substrate and product analogues Journal of the American Chemical Society $1002551-2560$

Moor RM, Kruip Th. AM and Green D (1984) Intraovarian control of folliculogenesis: limits to superovulation Theriogenology 21 103-116

Opel H and Nalbandov AA (1961) Follicular growth and ovulation in hypophysectomised hens Endocrinology 69 1016-1028

Pegg AE and McCann PP (1982) Polyamine metabolism and function American Journal of Physiology $243212-221$

Russell D and Snyder SH (1968) Amine synthesis in rapidly growing tissues: ornithine decarboxylase activity in regenerating rat liver, chicken embryo and various tumours Proceedings of the National Academy of Sciences USA 60 1420-1427

Sharp PJ, Scanes CG and Gilbert AB (1978) In vivo effects of an antiserum to partially purified chicken luteinizing hormone (CM2) in laying hens General and Comparative Endocrinology 34 296-299

Steele RGD and Torrie JH (1980) Principles and Procedures in Statistics (2nd Edn), pp 377-400. McGraw Hill Book Co., New York

Stewart F, Allen WR and Moor RM (1976) Pregnant mare serum gonadotrophin: ratio of follicle-stimulating hormone and luteinizing hormone activities as measured by a radioreceptor assay Journal of Endocrinology 71 371-382

Waddington D, Perry MM, Gilbert AB and Hardie MA (1985) Follicular growth and atresia in the ovaries of hens (Gallus domesticus) with diminished egg production rates Journal of Reproduction and Fertility 74 399-405

Wells JW, Culbert J, Gilbert AB, Walker MA and Davidson MF (1985a) LH stimulation of oestradiol production in vitro by small ovarian follicles in the hen (Gallus domesticus) IRCS Medical Science 1431091

Wells JW, Walker MA, Culbert J and Gilbert AB (1985b) Comparison of the response in vivo to luteinizing hormone and follicle stimulating hormone of the granulosa of six follicles from the ovarian follicular hierarchy in the chicken (Gallus domesticus) General and Comparative Endocrinology 59 369-374

White MW, Kameji T, Pegg AE and Morris DR (1987) Increased efficiency of translation of ornithine decarboxylase $\mathrm{mRNA}$ in mitogen activated lymphocytes European Journal of Biochemistry 170 87-92 